\title{
The Relationship between non-oil Trade and GDP in Petroleum Exporting Countries
}

\author{
Mohsen Mehrara \\ Faculty of Economics, University of Tehran, Kargar-e-shomali \\ Po Box 14166-6445, Tehran, Iran \\ E-mail address: mmehrara@ut.ac.ir
}

\begin{abstract}
This paper investigates the causal relationship between non-oil international trade and the GDP in a panel of 11 selected oil exporting countries by using panel unit root tests and panel cointegration analysis. A three-variable model is formulated with oil revenues as the third variable. The results show a strong causality from oil revenues and economic growth to trade in the oil exporting countries. Yet, non-oil trade does not have any significant effects on GDP in short- and long-run. It means that it is the oil and GDP that drives the trade in mentioned countries, not vice versa. According to the results, decision makings should be employed to achieve sustainable growth through higher productivity and substantially enlarging the economic base diversification in the future.
\end{abstract}

Keywords: Panel Unit Root; Panel Cointegration; Granger Causality; Oil Exporting Countries; Nonoil Trade

JEL classifications: $\mathrm{C} 33$; F13; F43

\section{INTRODUCTION}

Generally, it is argued that a more open economy has positive effects on output. The supporters of trade liberalization lay stress on the gains resulted from specialized production of goods with comparative advantage and claim that international trade growth causes technological change and innovation which result in economic growth. A more open economy allows imports of raw materials, foreign capital and advanced technologies for domestic production, increasing domestic productivity and efficiency. A more open economy also provide domestic production with a higher level of economies of scale through exports to international markets. Vamvakidis (2002), for example, showed that openness to international trade contributed to the rapid economic growth of East Asian economies, whereas less openness to international trade would have decreased economic growth.

Furthermore, there is the possibility of feedback effects from economic growth to international trade. It is argued that economic growth could increase international trade (Lie et al., 1997; Chang, 2002). Protectionists believe that trade liberalization is dreadful for growth and claim that economic openness in some countries makes economic growth and development worse. They believe in the strategy of supporting infant industries with tariffs and non-tariff laws. So it is not surprising that some countries are wary of the amount of trade 
liberalization. Thus, the above disputes suggest that a better understanding of economic growth requires the investigation of the relationship between openness to international trade and economic growth.

The focus of the paper is, therefore, to examine the relationship between non-oil trade and economic growth with oil revenues as the third variable in petroleum exporting countries for the period 1970-2011. The direction of causality between these two variables is examined by utilizing a co-integration and error correction modeling framework. The paper is organized in four sections. Section 2 provides a review of the empirical literature. Section 3 discusses the methodology and data. Section 4 shows the empirical results of the study. Section 5 concludes.

\section{EMPIRICAL LITERATURE REVIEW}

Ukpolo (1998) applied the Granger causality test to empirically determine the relationship between exports and economic growth in South Africa during the period 19641993. The evidence of his study indicates that exports and economic growth are cointegrated, which confirms the existence of a long run relationship between the two variables. In addition, the evidence seemed to verify the notion that economic growth Granger-causes export growth, but failed to support the export-led hypothesis that export growth causes economic growth.

Pradhan (2007) has examined export led growth (ELG) hypothesis for India using different approaches by employing data at the aggregate level covering the post-liberalisation period. By employing cointegration hypothesis (following the Johansen method), the study has investigated the Granger causality between export growth and GDP and export growth and investment. In this analysis, it fails to find support for the hypothesis that exports Granger cause GDP, using two measures for GDP (GDP with exports and GDP without exports). The same holds for the relationship between exports and investment. The finding strengthens the argument against the ELG hypothesis for the case of India.

Sami Ullah et al. (2009) have reinvestigated export-led-growth by time series econometric techniques (unit root test, cointegration and granger causality through vector error correction model) over the period of 1970 to 2008 for Pakistan. The results of the study reveal that export expansion leads to economic growth. They also have checked that whether there is uni-directional or bidirectional causality between economic growth, real exports, real imports, real gross fixed capital formation and real per capita income. The traditional Granger causality test in their research suggests that there is uni-directional causality between economic growth, exports and imports. On the other hand Granger causality through vector error correction has been checked using F-value of the model and t-value of the error correction term, which partially reconciles the traditional Granger causality test.

Amiri and Gerdtham (2011) have investigates the linear and nonlinear Granger causality between exports, imports and economic growth in France over the period 19612006 using geostatistical models. For testing the Granger causality in this study two methods have been applied (VEC and Improved-VEC with using geostatistical methods). Results from these two methods are same; both show the existence of long run unidirectional causality from exports and imports to economic growth. But in IVEC there are some different forms instead of linear (which is used in ordinary VEC) in Engle and Granger structures. It says that, the results of this improved-VEC are more exact and supportive than ordinary linear VEC method. 
Rahmaddi and Ichinashi (2011) examined the export and economic growth nexus in Indonesia during the period of 1971 to 2008. They investigated such relationship in a time series framework using a vector autoregressive (VAR) model. Based on findings of causality analysis conducted in VECM system, this paper has concluded that exports and economic growth exhibits bi-directional causal structure, which is ELG in long-run and GLE in shortrun. In addition it has found no supporting evidence of positive causality from intermediate imports to GDP per capita.

Amiri and Gerdtham (2012) has applied two methods (VAR and Improved-VAR using geostatistical methods) for testing the Granger causality in France over the period 1961-2006 with using geostatistical models. The results of linear and nonlinear Granger causality analysis in this study indicates that regardless of the sample considered there was unidirectional relationship from GDP to trade in France.

Results from these two methods were near; both show the existence of short run unidirectional causality from GDP toexports and imports. On the other hand, strong support for the existence of unidirectional relationship from exports to imports has been found based on Improved-VAR. Also, in Improved-VAR there have been a few nonlinear forms instead of linear in Engle and Granger structures. In general the results in Amiri's study support the GLE model in France.

\section{METHODOLOGY AND DATA}

We apply a three variable model to examine the causal relationship between non-oil international trade and GDP with oil revenues included in model as conditioning variable. Data used in the analysis include non-oil international trade (TRADE), Gross Domestic Product (GDP), and oil revenues (OILREV). Non-oil international trade is defined as share of non-oil exports and imports to GDP. We use annual data for the period of 1970-2011 for the selected oil exporting countries, gathered from World Development Indicators.

This study uses panel data for estimation. A panel unit root and co-integration approach, unlike the conventional time series one, has several benefits. First, by pooling time series and cross sections, finite sample power of test is significantly improved. Levin and Lin (1992), Levin, Lin, and Chu (2002), and Im, Pesaran, and Shin (1997, 2003) among others argue that power of panel unit root tests is considerably improved over univariate testing procedures. Mark and Sul (2001), Oh (1996), and Pedroni (1997, 1999, 2004) also indicate that the power of the panel co-integration approach is improved. Second, panel data analysis may provide more useful information on the nature of the economic system of equations for a group of countries compared to time series or cross sectional one.

To test the causal relationship between the variables while avoiding any spurious correlation, this paper follows three steps: We begin by testing for non-stationarity in the three variables of TRADE, GDP and OILREV. Prompted by the existence of unit roots in the time series, we test for long-run co-integrating relation between three variables at the second step of estimation using the panel co-integration technique developed by Pedroni (1995, 1999). Granted the long-run relationship, we explore the direction of the causal link between the variables using Granger causality test at the third step.

\section{1. Unit Root Test}

First of all, it is important to know if the variables are stationary. For this purpose, we should conduct unit root tests for the data of the variables of TRADE, GDP, and OILREV. 
Therefore, following the methodology used in earlier works in the literature, we test for trend stationarity of the three variables. The null hypothesis of the test is the existence of unit root or being non-stationary. The test is a residual based test that explores the performance of four different statistics. These four statistics reflect a combination of the tests used by Levin-Lin (1993) and Im, Pesaran and Shin (1997). While the first two statistics are non-parametric rhostatistics, the last two are parametric ADF t-statistics. The results of these four tests are shown in Table 1. The first three rows report the panel unit root statistics for TRADE, GDP and OILREV at the levels. As it can be seen in the Table, the results fail to reject the unit-root hypothesis when the variables are taken in levels and thus any causal inferences from the three series in levels are invalid. The last three rows show the panel unit root statistics for first differences of TRADE, GDP and OILREV. According to the results in the Table, the null of non-stationary at $1 \%$ level is rejected for all variables. Hence we can conclude that all the variables of TRADE, GDP and OIL are unit root variables of order one, or, I (1).

Table 1. Test of Unit Roots for TRADE, GDP and OILRev.

\begin{tabular}{ccccc}
\hline Variables & $\begin{array}{c}\text { Levin-Lin } \\
\text { Rho-stat }\end{array}$ & $\begin{array}{c}\text { Levin-Lin } \\
\text { t-Rho-stat }\end{array}$ & $\begin{array}{c}\text { Levin-Lin } \\
\text { ADF stat }\end{array}$ & IPS ADF stat \\
\hline TRADE & 0.32 & -0.52 & -0.72 & -1.56 \\
GDP & -1.11 & -1.19 & -1.32 & -0.86 \\
OILREV & -0.83 & -1.98 & -0.37 & -0.38 \\
$\Delta$ TRADE & $-14.66^{* * *}$ & $-7.98^{* * *}$ & $-11.63^{* * *}$ & $-17.98^{* * *}$ \\
$\Delta G D P$ & $-16.64^{* * *}$ & $-8.86^{* * *}$ & $-6.86^{* * *}$ & $-19.86^{* * *}$ \\
$\Delta$ OILrev & $-7.74^{* * *}$ & $-8.73^{* * *}$ & $-17.62^{* * *}$ & $-.17 .93^{* * *}$ \\
\hline
\end{tabular}

\section{2. Panel Co-integration Tests}

After conducting the unit root tests, it is time to apply panel co-integration tests to explore the long-run relationship between the three variables. Panel co-integration techniques have been developed in early 1980s and there is a lot of research in 1990s which has used these techniques.

Here, we apply panel co-integration technique developed by Pedroni $(1995,1999)$ in order to look for a long-run relationship between trade, GDP, and OILREV. This technique is a significant improvement compared to conventional co-integration tests applied on a single country series. While pooling data to determine the common long-run relationship, it allows the co-integrating vectors to vary across the members of the panel. After including OILREV as an additional variable, the co-integration relationship is specified as follows:

$$
T R A D E_{i t}=\alpha_{i}+\delta_{i}+\beta_{i} G D P_{i t}+\gamma_{i} \operatorname{OILREV} V_{i t}+\varepsilon_{i t}
$$


where $\alpha_{i}$ refers to country effects and $\delta_{t}$ refers to trend effects. $\varepsilon_{i t}$ is the estimated residual indicating deviations from the long run relationship. The null hypothesis of the panel cointegration test is not having co-integration. Pedroni (1999) refers to seven different statistics for this test. The first four ones are known as panel co-integration statistics, and the last three are group mean panel co-integration ones. In the presence of a co-integrating relation, the residuals are expected to be stationary. These tests reject the null of no co-integration when they have large negative values except for the panel-v test which reject the null of cointegration when it has a large positive value. All of these seven statistics under different model specifications are reported in Table 2. According to the statistics for all different model specifications, we reject the null hypothesis of no cointegration for all tests except the panel and group $\rho$-tests. However, according to Pedroni(2004), $\rho$ and pp tests generally under-reject the null hypothesis in the case of small samples. So it can be concluded that all the three variables of TRADE, GDP, and OILREV are cointegrated in the long run.

Table 2. Results of Panel Cointegration test.

\begin{tabular}{cc}
\hline Statistics & \\
\hline Panel v-stat & $6.72^{* * *}$ \\
Panel Rho-stat & -0.59 \\
Panel PP-stat & $-2.24^{* *}$ \\
Panel ADF-stat & $-4.72^{* * *}$ \\
Group Rho-stat & -0.92 \\
Group PP-stat & $-6.77^{* * *}$ \\
Group ADF-stat & $-6.28^{* * *}$ \\
\hline$* * *$ significant at 1 \% & \\
$* *$ significant at 5 \% &
\end{tabular}

\section{3. Panel Causality Tests}

As Granger $(1988,1969)$ has noted, co-integration implies that causality exists between the series at least in one direction, but it does not indicate the direction of the causal relationship. Knowing there is a long-run relationship among TRADE, GDP and OILREV, we conduct Granger causality test at the final step of estimation. Granger causality itself is a two-step procedure. The first step relates to the estimation of the residual from the long-run relationship. Incorporating the residual as a right hand side variable, the short-run error correction model is estimated at the second step. Defining the error term from equation (1) to be $E C T_{i t}$, the dynamic error correction model of our interest by focusing EX and GDP is specified as follows:

$$
\Delta G D P_{i t}=\alpha_{y}+\beta_{y i} E C T_{i t-1}+\sum_{j=1}^{n} \gamma_{y j} \Delta T R A D E_{i t-j}+\sum_{j=1}^{n} \delta_{y i} \Delta G D P_{i t-j}+\sum_{j=1}^{n} \lambda_{y j i} \Delta O I L R E V_{i t-j}+\varepsilon_{j i t}
$$




$$
\Delta T R A D E_{i t}=\alpha_{h i}+\beta_{h i} E C T_{i t-1}+\sum_{j=1}^{n} \gamma_{h j t} \Delta T R A D E_{i t-j}+\sum_{j=1}^{n} \delta_{h j t} \Delta G D P_{i t-j}+\sum_{j=1}^{n} \lambda_{h j i} \Delta \operatorname{OILREV} V_{i t-j}+\varepsilon_{h i t}
$$

where $\Delta$ is a difference operator; ECT is the lagged error-correction term derived from the long-run co-integrating relationship; $\beta_{y}$ and $\beta_{h}$ are adjustment coefficients and $\varepsilon_{y i t}$ and $\varepsilon_{h i t}$ are disturbance terms assumed to be uncorrelated with mean zero.

Sources of causation can be identified by testing for significance of the coefficients on the lagged variables in Eqs (2) and (3). First, by testing $H_{0}: \gamma_{y 1 i}=\gamma_{y 2 i}=\ldots=0$ for all $\mathrm{i}$ in Eq. (2) or $H_{0}: \delta_{h 1 i}=\delta_{h 2 i}=\ldots=0$ for all $\mathrm{i}$ in Eq. (3), we evaluate Granger weak causality. Masih and Masih (1996) and Asafu-Adjaye (2000) interpreted the weak Granger causality as 'short run' causality in the sense that the dependent variable responds only to short-term shocks to the stochastic environment.

Another possible source of causation is the ECT in Eqs. (2) and (3). In other words, through the ECT, an error correction model offers an alternative test of causality (or weak exogeneity of the dependent variable). The coefficients on the ECTs represent how fast deviations from the long run equilibrium are eliminated following changes in each variable. If, for example, $\beta_{y i}$ is zero, then GDP does not respond to a deviation from the long run equilibrium in the previous period. Indeed $\beta_{y i}=0$ or $\beta_{h i}=0$ for all $\mathrm{i}$ is equivalent to both the Granger non-causality in the long run and the weak exogeneity (Hatanaka, 1996).

It is also desirable to check whether the two sources of causation are jointly significant, in order to test Granger causality. This can be done by testing the joint hypotheses $H_{0}: \beta_{y i}=0$ and $\gamma_{y 1 i}=\gamma_{y 2 i}=\ldots=0$ for all $\mathrm{i}$ in Eq. (2) or $H_{0}: \beta_{h i}=0$ and $\delta_{h 1 i}=\delta_{h 2 i}=\ldots=0$ for all $\mathrm{i}$ in Eq. (3) This is referred to as a strong Granger causality test. The joint test indicates which variable(s) bear the burden of short run adjustment to re-establish long run equilibrium, following a shock to the system (Asafu-Adjaye, 2000). The results of the F test for both long run and short run causality are reported in Table 3.

Table 3. Result of Panel causality tests.

\begin{tabular}{|c|c|c|c|c|c|c|c|}
\hline \multicolumn{8}{|c|}{ Source of causation (independent variable) } \\
\hline \multirow{2}{*}{$\begin{array}{c}\text { Dependent } \\
\text { Variable }\end{array}$} & \multicolumn{2}{|c|}{ Short-run } & \multicolumn{2}{|r|}{ Long-run } & \multicolumn{3}{|c|}{ Joint (short-run/long-run) } \\
\hline & $\Delta \mathrm{GDP}$ & $\triangle \mathrm{TRADE}$ & $\triangle$ OILREV & ECT(-1) & $\begin{array}{c}\Delta \mathrm{GDP}, \\
\mathrm{ECT}(-1)\end{array}$ & $\begin{array}{c}\triangle \mathrm{TRADE}, \\
\text { ECT(-1) }\end{array}$ & $\begin{array}{c}\Delta \text { OILREV } \\
\text { ECT(-1) }\end{array}$ \\
\hline$\Delta \mathrm{GDP}$ & - & $\mathrm{F}=0.88$ & $\mathrm{~F}=5.41^{* * *}$ & $\mathrm{~F}=0.51$ & - & $\mathrm{F}=0.55$ & $\mathrm{~F}=4.26^{* * *}$ \\
\hline$\triangle \mathrm{TRADE}$ & $\begin{array}{c}\mathrm{F}= \\
2.77^{* *}\end{array}$ & - & $\mathrm{F}=4.71^{* * *}$ & $\mathrm{~F}=4.98^{* * *}$ & $\mathrm{~F}=5.36^{* * *}$ & - & $\mathrm{F}=6.81^{* * *}$ \\
\hline
\end{tabular}

As it can be seen in the Table, the coefficients of the ECT, GDP and OILREV are significant in the trade equation which indicates that long-run and short-run causality run from GDP and OILREV to TRADE. Therefore GDP and OILREV strongly Granger causes TRADE. In addition, OILREV does Granger cause GDP at short run at $5 \%$ level, without 
any significant effect on output in long-run. Weak exogeneity of GDP indicates that this variable does not adjust towards long-run equilibrium.

Moreover, the interaction terms in the trade equation are significant at $1 \%$ level. These results show that there is Granger causality running from GDP and OILREV to TRADE in the long-run and short-run, while non-oil trade has a neutral effect on GDP in both the shortand long-run. In other words, GDP is strongly exogenous and whenever a shock occurs in the system, non-oil trade would make short-run adjustments to restore long-run equilibrium.

\section{CONCLUSION}

The objective of this study was to examine Granger causality between non-oil trade and income for oil-exporting developing countries over the period 1970-2011. Oil revenues are also included in the model along with these two variables. The panel integration and cointegration techniques are employed to investigate the relationship between the three variables: non-oil trade, GDP, and oil revenues. Utilizing Granger Causality within the framework of a panel cointegration model, the results suggest that there is strong causality running from GDP and oil revenues to non-oil trade with no feedback effects from non-oil trade to GDP for oil exporting countries. Moreover, oil revenues have significant effects on GDP just in short-run. It means that it is the oil and GDP that drives the non-oil trade in mentioned countries, not vice versa. The weak effect of non-oil trade on GDP growth shows that implementation of tariff reduction and export development can not solely lead higher economic growth. Our findings challenge the empirical literature regarding the ELG (exportled growth hypothesis) hypothesis and expresses serious doubts with regard to promoting trade as a comprehensive development strategy. The ELG is possibly favorable only for a limited number of developing countries, and only to a certain extent.

\section{Acknowledgements}

The authors would like to acknowledge the financial support of university of Tehran for this research under the grant number 4401012/1/21.

\section{References}

[1] Anwer M. S., Sampath R. K., 1997. Exports and Economic Growth. Presented at Western Agricultural Economics Association 1997 Annual Meeting, July 13-16, 1997, Reno/Sparks, Nevada.

[2] Asafu-Adjaye J., Energy Economics 22 (2000) 615-625.

[3] Balassa B., Journal of Development Economics 5(2) (1978) 181-189.

[4] Balassa B., 1980. The Process of Industrial Development and Alternative Development Strategies. Princeton Essays in International Finance, No 141, December (Princeton, NJ: Princeton University, Department of Economics).

[5] Balassa B., Journal of Development Economics 4(1) (1985) 23-35.

[6] Ekanayake E. M., Journal of Economic Development 24(2) (1999) 43-56.

[7] Feder G., Journal of Development Economics 12(2) (1983) 59-73. 
[8] Granger C. W. J., Econometrica 37(3) (1969) 424-438.

[9] Granger C. W. J., Journal of Econometrics 39 (1988) 199-211.

[10] Hatanaka, M., 1996. Time-Series-Based Econometrics: Unit Roots and Cointegration. Oxford University Press, Oxford.

[11] Im K. S., Pesaran M. H., Shin Y.,1997. Testing for Unit Roots in Heterogenous Panels. University of Cambridge, Department of Applied Economics.

[12] Im K. S., Pesaran M. H., Shin, Y., Journal of Econometrics 115 (2003) 53-74.

[13] Jun Sangjoon, Journal of Economic Research 12 (2007) 133-171.

[14] Lee Chien-Hui, Huang Bwo-Nung, Journal of Economic Development 27 (2) (2002) 45-68.

[15] Levin A., Lin C. F., 1992. Unit Root Tests in Panel Data: Asymptotic and Finite Sample Properties. Department of Economics, University of California at San Diego, Working Paper 92-23.

[16] Levin A., Lin C. F., 1993. Unit Root Test in Panel Data: New Results. Department of Economics, University of California, San Diego, Working paper 93-56.

[17] Levin A., Lin C. F., Chu C. S. J., Journal of Econometrics 108 92002) 1-24.

[18] Mark N., Sul D., Journal of International Economics 53(1) (2001) 29-52.

[19] Masih A. M. M., Masih R., Energy Economics 18 (1996) 165-183.

[20] Pandhi D., 2007. The Relationship between Exports and Growth in Select African Nations. A Senior Honors Thesis Presented in Partial Fulfillment of the Requirements for graduation with research distinction in Economics, The Ohio State University.

[21] Pedroni P., 1995, Panel Cointegration: Asymptotic and Finite Sample Properties of Pooled Time Series Tests, with an Application to the PPP Hypothesis. Indiana University, Working Papers in Economics, No. 95-013.

[22] Pedroni P., Oxford Bulletin of Economics and Statistics 61(4) (1999) 5-49.

[23] Pesaran, M. H., Shin Y., 1997. An Autogressive Distributed Lag Modelling Approach to Cointegration Analysis, Working Paper Trinity College, Cambridge.

[24] Pop-Silaghi M., Romanian Journal of Economic Forecasting 2 (2009) 105-117.

[25] Safdari, M, Mahmoodi, M., Mahmoodi, E., The Causality Relationship between Export and Economic Growth in Asian Developing Countries. American Journal of Scientific Research (2011) 40-45. 